\title{
The variety of attitudes among palaeontologists faced with evolution (1840- 1870)
}

\section{Marc GODINOT}

Ecole Pratique des Hautes Etudes, UMR 7207 CR2P, Case Postale 38, Département d'Histoire de la Terre, Muséum National d'Histoire Naturelle, 8, rue Buffon, 75231 Paris Cedex 05, France. godinot@mnhn.fr

Godinot, M. 2012. The variety of attitudes among palaeontologists faced with evolution (1840-1870). [Variedad de actitudes frente a la evolución entre los paleontólogos (1840-1870)]. Spanish Journal of Palaeontology, 27 (2), $143-158$.

\begin{abstract}
A variety of attitudes existed among paleontologists faced with evolution, or transformism, in 1840-1870. D'Orbigny, forcefully contributing to stratigraphy, was a catastrophist and a natural creationist. Brongniart, also catastrophist, had a more religious blend of creationism. D'Omalius d'Halloy and Gérard were explicitely transformists before Darwin, the former being religious and the latter not. Bronn and d'Archiac had a continuous view of the history of life, yet were not transformists, for scientific reasons. Gaudry became an enthusiastic evolutionist and was religious. Their different philosophico-religious opinions reveal that, in their varied attitudes toward transformism, scientific considerations were far more important than anything else; philosophical considerations played a role, and religious choices had little influence.
\end{abstract}

Keywords: History of palaeontology, evolution, creation, fossil record.

\section{RESUMEN}

Entre los paleontólogos del periodo 1840-1870 existió una variedad de actitudes frente a la evolución, o transformismo. D’Orbigny, un enérgico contribuyente a la estratigrafía, fue un catastrofista y creacionista natural. Brongniart, también catastrofista, tuvo una visión más religiosa del creacionismo. D'Omalius d'Halloy y Gérard fueron explícitamente transformistas antes que Darwin, siendo religioso el primero mientras que el segundo no lo era. Bronn y d'Archiac, por razones científicas, tuvieron una visión continuista de la historia de la vida, aunque no fueron transformistas. Gaudry llegó a ser un evolucionista entusiasta aunque fuese religioso. Sus distintas opiniones filosófico-religiosas revelan que, en sus diferentes actitudes hacia el transformismo, las consideraciones científicas fueron mucho más importantes que ninguna otra cosa; las consideraciones filosóficas jugaron algún papel, y las elecciones religiosas tuvieron poca influencia.

Palabras clave: Historia de la paleontología, evolución, creación, registro fósil. 


\section{INTRODUCTION}

In retrospect, one can really wonder why palaeontologists did not immediately become evolutionists when "On the Origin of Species by means of ..." appeared at the end of 1859. Most accounts of the history of science in the XIXth century, especially the history of biology, give an immense importance to this date, often as the starting point of a "Darwinian Revolution". This revolution is thought to have been so profound because it did not affect only science, it also had large consequences on society through philosophy and religion. This "concomitant ideological revolution" was "even true of the reaction of scientists, since scientists - like other human beings - tend to be strongly influenced in their judgments by philosophical, religious, and other preconceptions" (Cohen, 1985, p.283284). This view is pervasive in the history of paleontology of Grimoult (2000), who presents palaeontologists permanently confronted with the choice transformism versus creationism, and choosing most of the time in relation with their religious preconceptions. Is this true of the palaeontologists who reacted very negatively to Darwin, or did not accept transformism before? I will not in this brief essay treat all these questions, which would request a book. However, I will introduce to the life and works of some geologists and palaeontologists who deserve to be known, showing the real complexity of this history, the central role played by the state of palaeontology at their time, and probably a less important role for religious preconceptions than has often been assumed. Meanwhile, it will become clear that, contrary to some historical accounts, evolution was a concern in France and around in the decades before Darwin. I will successively consider: two palaeontologists who were not transformists and preferred a recourse to creation, d'Orbigny and briefly Brongniart; two scientists who were supporters of evolution before Darwin, d'Omalius-d'Halloy and Gérard; two other palaeontologists who slightly later, between 1850 and 1860 , could still not accept transformism, Bronn and d'Archiac; and endly Gaudry, enthusiastic evolutionist, who found excitment in reading Darwin but never shared the philosophical ideas of the latter. In the following text, translations from French are mine; they try to stay as close as possible to the original language, which often sounds old-fashioned; French original terms are indicated in square brackets when the literal translation seems not to be exact.

\section{REFUTATION OF TRANSFORMISM AND NATURAL CREATIONISM BY D'ORBIGNY}

Alcide d'Orbigny (1802-1857) started his scientific career in studying foraminifera (first classification in 1826). He travelled to South America during seven years (18261833), coming back to the Paris Museum with 9,000 species and drawings for the collections. He published between 1835 and 1847 his "Voyage dans l'Amérique méridionale", 11 volumes containing ethnology, geography, geology, palaeontology, zoology and botany. This magnificent work was considered by Darwin, who was himself in South America from 1831 to 1834, as "one of the monuments of science in the XIXth century". Back from South America, d'Orbigny became enthusiastic for palaeontology. He travelled all over France and, with the help of correspondents, assembled a large collection of fossils (around 100,000), all having a well established geological provenance. Most were marine invertebrates, and he began systematic revisions of the different groups in his "Paléontologie Française", published from 1840 until after his death (1860). In these 8 volumes including 1,440 plates, he described 2,800 species of fossil invertebrates, 2,100 of which were new for science. He also realized studies in marine zoology, allowing him to frequently infer from the environment of living species to that of fossil species of the same groups. He then started an even more ambitious project, a synthesis of palaeontological knowledge in his "Cours Elémentaire de Paléontologie et de Géologie Stratigraphiques" (1849, 1852), backed up by synthetic tables of all known fossils, published in his accompanying "Prodrome de Paléontologie stratigraphique universelle des Animaux mollusques et rayonnés" (18501852). For the latter, he consulted more than 200,000 references (Vénec-Peyré, 2002). D'Orbigny is well-known for having defined the concept of geological stage. He established the foundations of biostratigraphy, in line with predecessors and British and German geologists who he cites. He presented a first stratigraphic scale with as much as 27 stages before our time, 19 of which are still in use. He was clearly in the school of Cuvier, however all along the Cours Elémentaire, he explains on what geological evidence he bases his conclusions, which are: there were long periods of equilibrium, then faunas and floras were abruptly destroyed by catastrophes linked to tectonics, and replaced by successive creations. D'Orbigny was later criticized for his use of creations and went into disgrace long after his death in 1857. Some historians consider that he must have been under a strong religious influence, e.g., Grimoult writes that for him as for Cuvier or de Beaumont "there is no doubt that God came back on earth several times to create, ex nihilo, new species"; he also writes that the succesive creations are "of more or less miraculous nature" (Grimoult, 2000; p. 23, 29). However, such a claim appears to me unfounded and misleading. The conceptions of d'Orbigny appear on the contrary as rational, scientific, firmly grounded on an enormous quantity of empirical evidence, and out of any recognizable religious influence. 
The Cours Elémentaire being a systematic review of stratigraphy, zoology and palaeozoology, followed by a review of faunas and floras through geological stages, d'Orbigny's conceptions are not simply outlined in an introduction. However, they are straightforward, and I will summarize them in four points: 1) there are no transitional forms; 2) there is no general progress in organization through geological time; 3 ) factors proposed by transformists to explain evolution cannot have played their presumed role; and 4) catastrophism and successive creations are the only possible explanation of known facts.

1) The absence of transitional forms is already a common conclusion of d'Orbigny in his different volumes of the Paléontologie Française. For example, after a careful revision of ammonites coming from Cretaceous beds, he concludes: "From all what precedes, fidel expression ["exposé"] of facts that I was able to observe on Ammonites, I believe that one can drive the following conclusions, which bear a high interest for the succession order of beings at the surface of the globe, and in the application of their forms to the recognition of beds: $1^{\circ}$ there are clear-cut limits between faunas belonging ["propres à"] to each bed or formation, because no species of Ammonites goes from jurassic to cretaceous beds. [...] $5^{\circ}$ The different stages of the cretaceous beds, at the same time as offering affinities and reciprocal links of Ammonite groups ["des passages réciproques"], have nevertheless distinct exterior forms, nature having, at each epoch, varied her productions and having given them a global facies ["un faciès d'ensemble"] easy to seize"(d'Orbigny, 1840; p. 437-438). He is even more explicit in his conclusions concerning Cretaceous gastropods: " $6{ }^{\circ}$ In all cases, species of Gastropods are distinct by bed ["terrain"], and according to stages of these beds. All can serve to have them recognized, whatever the mineralogical form under which these stages appear. $7^{\circ}$ No transition showing up in specific forms, beings seem to succeed eachother at the surface of the earth, not by transition ["passage"], but by extinction of existing races, and by renewal of species, at each geological epoch" (d'Orbigny, 1842; p. 423). In many instances, in the Paléontologie Française and in the Cours Elémentaire, d'Orbigny will repeat that in his (big) documentation there are no transitions between species of succeeding stages. This is true. However, this general conclusion should not mask a complementary view, expressed in comments on genera, orders, classes, that there is quite an amount of continuity in this history of life. For example, in his chapter on the Saliferian stage, his second Triassic stage, he comments the "positive paleontological characters extracted from genera" in these words: "The higher number of genera which are born than of genera which disappear with this epoch, demonstrates that the Saliferian stage is the beginning of a new period of animal forms which continue in Jurassic beds. With Ammonites, Trigonies and many other Mollusk genera more developped in the following period, also appear a rather large number of Zoophytes astréidées and of Amorphozoaires testacés [groups of corals and sponges], which will develop even more in Jurassic beds. These general characters are even more remarkable as they perfectly coincide with what $\mathrm{M}$. Brongniart finds for the flora of this epoch, fully intermediate between the Conchylian stage and the first stages of the Jurassic" (d'Orbigny, 1852, p. 409). Another example: "It is, indeed, in Triassic beds that are born the first traces of birds, turtles, decapod crustaceans, and acetabulifer cephalopods, which show such a wide development in the following epoch" (idem; p. 387). All along his writings, the insistance of d'Orbigny on species discontinuities between successive stages, implying successive creations, does not prevent the recognition of a broad general historical continuity of higher systematic groups.

2) D'Orbigny discusses on five pages the "Increasing or decreasing periods, in the world ages, of animal orders compared to the perfection of the whole of their organs", and he continues with physiological and climatological considerations, concluding against evolution after 22 pages. Comparing orders, he finds 64 to be in their period of increasing generic number, and 13 to be in their decreasing period. He concludes: "When one sees, indeed, 13 orders among 77, or more than one sixth of the whole number, to be in their decreasing period of development of zoological forms, one must naturally conclude that all the animal series have not followed a uniform walk in the world ages. One sees there again an important exception to this too often admitted law of progressive perfectioning of beings, in going from ancient to more modern epochs" (d'Orbigny, 1852; p. 320-321). He continues in comparing the four phyla ["embranchements"] of animals with their degree of perfection; in the most perfect, the vertebrates, he finds that among mammals, two orders, Pachydermes and Edentates, which are in their decreazing period, "are without doubt more perfect than Cetaceans, still in increasing way". He concludes his survey: "In summarizing about the whole of increasing and decreasing periods of animal orders compared with world ages, one sees that, according to the number of orders, the majority would still be in the increasing way; whereas, according to the value of physiological characters compared with age, all the numerical results disappear to give way to the most certain demonstration of the non-successive-perfectioning of beings [le "non-perfectionnement successif des êtres"]" (idem; p. 224).

At the time he writes, the known fossil record starts with the Silurian, in which the four phyla exist, and these, as well as their classes, show parallel lines of history, and not a succession according to their degree of perfection: 
"last conclusion which completely destroys the successive perfectionning of beings, in going from the most ancient epoch to the present" (idem; p. 225). He continues and strengthens his analysis in studying the "instant of appearance" of groups in comparison with their degree of perfection. He is aware that mammals appear late, however he shows that they are an exception: "The accordance of the increasing degree of perfection of organs, in going from the first ages of the world to the present epoch, far from being a constant rule, as one had been able to believe in studying mammal animals, is on the contrary, only a weak exception to the general parallel path, and which is only based on the late arrival on the earth of the Mammal Order. This accordance, even under this view, would exist only for one nineteenth of the whole of classes". A next conclusion is: "It would again result from what precedes that animals, far from successively perfectioning their organs and passing through all degrees of perfection through world ages, have often in this regard less gained than lossed in several phyla, or remained at least stationary, which entirely excludes the general increasing way from simple to complex ["composé"] in the course of geological ages" (idem; p. 231). If there is no incresase in complexity through time, evolution, or transformism, is not possible. At the time of d'Orbigny no fossils were known from the Cambrian and the Precambrian, so that his views were broadly correct, even if concepts of progress or perfection would now be considered inaccurate. The fossil record was emphatically not showing a global evolution.

3) D'Orbigny addresses the factors invoked by transformists to explain evolution; he does not mention Lamarck, however he clearly addresses Lamarckian factors (Laurent, 2002). Knowing well the physiology and the environment of marine invertebrates, he is able to show that the marine milieux have not drastically changed since the Paleozoic. Not only invertebrates but also fishes, "with the possible exception of the configuration of the scales which cover them, had the same gills and the same organic characters as nowadays fishes" (idem; p. 235). Thus, they did not progress, and their environments did not change much. Among a series of conclusions, " $3{ }^{\circ}$ No substancial modification existing in the respiration of beings, from the most ancient epochs to the present; a large number of genera having always existed with similar characters, from the first animalisation of the globe to the present, one must believe that vital elements did not change, and that milieux of existence remained the same on continents and in seas. $4^{\circ}$ Milieux of existence having always remained the same on continents and in seas, no change in the milieux of existence can have, from this, influenced on extinction and on renewal of successive faunas, which we see replace eachother so many times, at the surface of the globe, since the first animalisation until the present epoch: conclusion of an immense scope for the chronology of the ancient world, and of the beings which populated it at all geological epochs" (idem; p. 238-239). It is difficult to be more explicit against one of the Lamarckian factors of evolution. D'Orbigny continues with climatological considerations which show that marine faunas of the past are similar to present day warm ocean faunas: "As we see, since the beginning of the world until the last Tertiary stage, faunas typical of warm regions succeed eachother, regularly and everywhere, in the seas and on the continents, it is impossible to ascribe to the action of temperature any of the numerous successive changes of faunas which existed in the ages of the globe" (idem; p. 242); this is probably an answer to d'Omalius d'Halloy, who invoked in his "Eléments de Géologie" the action of changes in temperatures and other factors to explain changes in his evolutionary views (see below). In sum, d'Orbigny carefully refuted the arguments of those who had adopted the transformist views of Lamarck (we know through the work of Laurent and Corsi that they were numerous).

4) The only view which could fit with his observations was that of successive stages separated by extinctions and renewals of faunas. "As one can see at the last part of this work, the most rigorous stratigraphical considerations, based on the comparative study of all the stratified beds of the globe, lead to conclude that there were, since the beginning of the animated world until the present, twentyseven successive ages, each containing a special peculiar fauna. By looking at our Prodrome de Paléontologie stratigraphique universelle des Animaux mollusques et rayonnés, one finds, indeed, spread between these twentyseven stages, more than 18,000 species pertaining to mollusk and rayonés animals, of which the joined table shows comparative numbers by stages" (idem; p. 249, 251). When adding vertebrates and "annelés", the total increases to 24,000 species, of perfectly well known age repartition. "These 24,000 species are thus 24,000 facts which notice the succession, in a constant chronological order, on all parts of the world, of faunas distinct by stages, and which replaced eachother, since the first animalisation of the globe until the present. [...] the constant facts are the extinction and the creation of faunas" (idem; p. 251).

Concerning extinctions, d'Orbigny exposes the geological arguments which link limits of stages with changes in marine limits, areas of sinking of the earth crust and other tectonic movements linked to mountain chains and oceans (the broad picture of which cannot be explained for him by present day causes, in actualistic terms). When he arrives to face creations, d'Orbigny becomes very embarrassed: "If our researches lead us, through facts, to explain faunal extinction, nothing can unveil to us the mysteries attached to the successive creations of the first until the last periods of the living world... How was formed this multitude of beings which covers, for the first time, the surface of the earth? ... What is the creative force which 
has had such an extraordinary all-might? Here we must confess our complete unability to find an answer to any of these high questions. There are limits that the human spirit cannot cross, circumstances in which man must stop and content himself with accepting facts that he cannot explain" (idem; p. 251).

Several remarks follow. In this text, there is only recourse to a "creative force", which remains mysterious. However, such a creative force was often mentioned by scientists and attributed to nature, sometimes explicitly as a natural force. D'Orbigny uses creative force and creative power ["puissance créatrice"], never with capitals, and he never refers to God or to Scripture (his mention of the deluge as a recent catastroph is brief and limits its impact). In fact, in many other writings, as seen above, one can find explicit references to the power of nature. He often talks of whole groups as if they were expanding themselves through time. For example, in his eigth conclusion about gastropods, he wrote: "Gastropods, taken as a whole, have, according to the chronological order of faunas proper to stages, gone from the simple to the complex ["composé"]. Many genera, unknown in Jurassic beds, show up with..., others..., an even larger number..., as if nature was perfectioning herself more and more, in nearing us" (d'Orbigny, 1852; p. 423). Later, he writes: "In sum, why wants one, only by a spirit of system, give hindrance to the creative power? Why wants one to prevent nature to reproduce, several times ["à diverses reprises"], in the ages of the world, analogous forms,..." (d'Orbigny, 1850). It is thus clear to me that d'Orbigny is referring creations to an unknown natural power or force, as was the case of other palaeontologists. His dedication to the accumulation and to the control of facts, to deductions, his modern way of paying attention to intraspecific variability, reveal his intellectual qualities and his strong commitment to the movement of positive science in which he explicitly placed himself. There is simply nothing religious in his views. I suspect that his frequent use of the "first animalisation of the globe" is a way (his invention?) to avoid as much as possible the word creation with the meaning of creation de novo; the uncommon term of animalisation in French sounds like a process, a presumed natural process. D'Orbigny tried as much as possible to avoid "the spirit of system", "preconceived ideas". He tried to avoid excessive speculations, for example concerning the duration of catastrophs and recoveries. He contended himself to propose that some stages had longer durations than others because they left thicker beds. He can be criticized for sometimes coming close to circular reasoning, for forcing facts into his own system, or for some exaggerations. However on the whole his enormous amount of work appears as good science of his time; his recourse to creations is a conclusion and at the same time an honest confession of ignorance concerning the processes. I think that his view is one of those who would deserve the qualification of scientific creationism, if the term had not been spoiled by the recent "creation science" which is not scientific but religious in essence (Numbers, 2006). The best way to qualify his views appears to me as scientific catastrophism and natural (philosophical) creationism. In any case, his opposition to transformism is clearly scientific and not philosophic or religious.

I will briefly mention a short text of Adolphe Brongniart (1801-1876), which shows a more religious nuance in ideas very close to those of d'Orbigny. This palaeobotanist, son of Alexandre Brongniart who worked with Cuvier, had started in 1828 to publish some of the funding memoirs of palaeobotany. He arrived to a view of successive creations under the influence of Deshayes and d'Orbigny (Bourdier, 1960). In 1857, in his comments on the Academy prize (see below), he wrote: "in the midst of the obscurity surrounding such mysteries, and that our mind tries in vain to penetrate, let's recognize that it is less difficult for our intelligence to conceive that the divine power, which created the first living beings on the earth, did not rest and continued to exert the same creative power at the other geological periods, giving to the whole of these successive creations the characters of greatness and unity that the naturalist even more than the other men is led to admire in all its works" (Brongniart, 1857). Here Brongniart clearly appeals to the divine power, however it is interesting to see why: he considers that the questions of origins are so little understood, so unpenetrable to our minds, that he finds it easier for his intelligence to appeal to the divine power. It is his rational choice. Many scientists still had such a recourse for the beginning of life, for the sudden appearance of several kinds of animals in the oldest fossiliferous rocks then known. Why not extend such a recourse through time? Again it is a confession of ignorance that he is doing, adding to it a philosophical jump (to a god of the philosophers or to a god of scripture, we don't know). It is not apologetic, despite his admiration for the greatness of the living world. I find his attitude closer to an intellectual honesty, the recognition of our ignorance, than to a religious obedience. However, his creationism has a more philosophico-religious blend than that of d'Orbigny.

\section{TWO EVOLUTIONISTS BEFORE DARWIN: D'OMALIUS D'HALLOY AND GÉRARD}

Sharing the same commitment to science as d'Orbigny, however adopting a different philosophical attitude toward the interpretation of historical facts, some other scholars became real evolutionists at the same period, and before Darwin. The first of them, Jean-Baptiste Julien d'Omalius d'Halloy (1783-1875), was a Belgian geologist. Coming 
to Paris at 18 to fulfill his education, he soon became enthusiastic for the courses given at the Muséum National d'Histoire Naturelle (Cuvier, Haüy, Lamarck, Geoffroy Saint-Hilaire). Taking precise notes of the geological beds during his travels by feet in France starting in 1804, he publishes at the age of 25 years an essay on the geology of Northern France which gave him an immediate recognition. Escaping to be enrolled in Napoléon's army, he continued his geological work, elaborating his geological map of France (achieved in 1813, published in 1822). This masterwork makes him one of the founders of European geology. For political reasons, he left geological research to become governor of Namur Province in 1814. He later came back to geology and decided to publish a short textbook of geology, achieved in 1830 but published in 1831 due to the political events.

In these "Eléments de Géologie", several times reprinted, he clearly appears transformist. In his first considerations on "organized bodies burried in the solid crust of the globe", he observes: "the more one sinks in the crust of the globe, the more the change in composition becomes complete, and the more the species become different from those which live presently" (d'Omalius d'Halloy, 1831; p. 75). Below, writing about Tertiary beds: "lower again living genera have almost entirely disappeared; those which are close are less abundant, and the class of mammals is almost entirely represented by paleotheres, anoplotheres, cheropotames and other pachyderms very different from our living animals, and which resemble only some anomalous genera which remain, so to speak, on the earth, to link ancient times with modern times" (idem; p. 76). He describes successively all beds ("terrains") from the most recent to the oldest, and then all kinds of plutonic rocks and formations. He all along lists the known fossils. In his last chapter on "antediluvian phenomena", he discusses the question to know "if there were several creations, or if there was simply partial destruction with geographical displacements of species, or, endly, if reproduction can have produced this succession of different forms that we have observed. The idea of a series of new creations is a purely gratuitous hypothesis which is grounded in no analogy with phenomena which occur since historical times; and ["or"], it seems that one shall recourse to such hypotheses only when it is absolutely impossible to explain facts otherwise, which does not occur in the present case" (idem; p. 526-527). He then explains why the hypothesis of successive partial destructions is extremely unlikely in view of the already important known fossil record. He then turns to "the hypothesis of successive change of living beings by way of reproduction", which "can, on its side, be attacked by the consideration that in the present state of things, species have a stability of forms that does not allow to suppose changes similar to those offered by the succession of fossil organized bodies; however as high as this stability be it is nevertheless not absolute, and if we examine under this point of view the natural history of present living beings, we will see that different causes still lead to changes in their forms" (idem; p. 528). The principal cause is the action of man, who by changes in diet and temperature of their environment, succeeded in changing flowers and fruits, "and to give to domesticated animals qualities and forms so different, that zoologists are forced to leave in the species $d o g$, a collection of animals, within which some differ between them much more, than a fox differs from a wolf. Changes of this kind also occur without man's care, through changes of the circumstances under which living beings find themselves" (idem; p. 529). After enumerating factors linked to transport of species or changes in diet, he writes that all these "are quite weak causes, in comparison with great geological phenomena" (idem). After a listing of many kinds of geological changes at the surface of the earth, he concludes that "all these causes together must unquestionably exert on vital movement an influence, the energy of which we cannot well determine, but that one can consider as sufficient to have led to the changes in forms that we have remarked in the succession of living beings" (idem; p. 530). In a long footnote, he then develops the idea that one cannot deduce from this anything concerning the immateriality of the human soul, and goes into some strange comments to explain that geological facts do not destroy Genesis and the teaching of religion, an attitude apparently not entirely consistant (see de Bondt, 2007). Anyway 1831 is quite an early date for these debates, and the choice of evolution by a prominent geologist, based on fossils and other considerations, is noticeable.

D'Omalius d'Halloy was a member of the Société Géologique de France, of which he was even one year elected president, despite foreign citizen, and he attended its meetings regularly during many years (de Bondt, 2007). In 1848, he defended again his transformist views in a meeting of this Society. In his paper, he extends the discussion published in his book. He starts saying that causes concerning changes of organized beings which succeeded eachother at the surface of the earth "cannot, as all hypothetical considerations, in general, be considered true science", however the tendancy of the human spirit is such that "the development of these hypotheses has until a certain point taken place at the side of the study of facts, and that it has always more or less occupied scholars" (d'Omalius d'Halloy; 1846, p. 490). He recalls his earlier choice and, seing that most geologists consider several creations preceded by complete destructions of living nature, says that he is "far from giving to such hypothetical opinions more importance than they deserve". He confesses having been impressed by the expanding doctrine that "the diverse systems of organisms were so clear-cut that no species from one system was ever found associated with one of another system" (idem; p. 491; clearly addressed to d'Orbigny). However this new view is itself changing 
with new evidence, which prompts him to come back on "the motives which lead me again to consider the hypothesis I admitted as that which best agrees with the ordinary way of nature [celle qui s'accorde le mieux avec la marche ordinaire de la nature; p. 491]". He details again and update and complete his arguments. For example, against the objection that changes under domestication or artificial crystals would be only human art, he wrote (in another print of his book) that "all that man does in this regard, is to dispose things in such a manner that certain natural law, the action of which was paralyzed, finds itself in circumstances which facilitate its development" (idem; p. 492). The objection that there are no transition between ancient species and living ones would be very important, "if zoologists agreed on the principles which determine species and on the application of these principles; $[. .$. However, one is tempted to say that "the determination of species among paleontologists, instead of being based on characters taken only from observed bodies, is the result of theoric ideas, as we see that authors who think that each geological period corresponds to a completely independant organic population give different specific names to beings which, for other paleontologists, only form varieties of the same species" (p. 492). There are uncertainties not only in palaeontology but also in zoology. He remarks that there is not yet a good definition for living species, and that the most often used are based on the origin of those species, which is more or less hypothetical (species are supposed to be fixed, to be descended from exactly similar ancestors). He questions the idea that descendants must always bear the same characters as their ancestors: is this in accordance with modifications produced under our eyes by external causes and by breeding? In a long footnote in which he criticizes the common objection of "return to the primitive type" of hybrids, he adds that "the hypothesis of species modification just received a new support by the recently made discovery, of animals which have the faculty to reproduce before having taken their last form; as one can conceive that if a general and permanent cause advented which prevented those animals to accomplish their last metamorphosis, a new series of beings would be established which would form a species different from that of their ancestors, species which could even pertain to a class different from the ancestral ["originaire"] species, as in the case of these Polypes..." (idem; p. 494). Here d'Omalius refers to the recent discovery of neoteny by his colleague van Beneden. It is remarkable that in seing its evolutionary significance, he anticipated developmental heterochronies (Groessens \& Groessens-van Dyck, 2007). He concludes that "whatever the present stability of species, the modifications of living beings are not a phenomenon foreign to present-day nature", and that to apply to those early modifications limits much broader than presently is only to apply to organic nature the same principles that most geologists apply to the inorganic world. This is a very rational attitude because "causes wich we suppose to have given more force to the physical phenomena are also such as ["de nature à"] to give more energy to physiological phenomena" (idem; p. 495). He then comes back to a criticism of successive creations, and says that, in front of the objection that a first creation being supposed, then it is not going out of the natural order to suppose several, in fact "the supposition of a first creation is not even a consequence of observation, [...]. The naturalist must confess that the first cause of the vital movement is no more known to him than that of physical movements, and that natural sciences must stop in front of researches which are no more of their domain" (idem; p. 495). In a long footnote, he recalls that on several occasions he expressed that one should avoid introducing religious considerations in discussions on natural sciences. He adds that on one side one has introduced "the dogma of creation in the question we address", and on the other side the hypothesis of species modification was attacked as contrary to religious beliefs. He observes that the hypothesis of several creations preceded by complete destructions "is much more contrary to the text and to the spirit of our sacred books than that of certain modifications in the forms of living beings" (p. 496). He further comments on Genesis, and in a following footnote gives a balanced criticism of the expression "tendancy toward perfection". His communication ends with "I persist then to believe that this last hypothesis [the modification of living beings] is much more in accordance ["en rapport avec"] with the present state of things than those which suppose that new forms appeared on the earth otherwise than by generation of preexisting beings" (idem; p. 497). A following discussion is reported, starting with Agassiz who says that "paleontologists who talk about repeated creations ["réitérées"] borrow their arguments to fossils only", and that if he agrees with examples from domesticated animals and plants, it is man who modifies them, adding: "Modifications in different geological beds are from a very different nature" (Agassiz, in idem). Boubée defends that man was created after many organized beings, and that "one would not deduce him from any preexisting stem ["on ne saurait le déduire d'aucune souche préexistante"]; he then protests against the idea that there was no creation, and even several successive creations "when this is the most definite and the brightest conclusion of so numerous observations already collected on the whole earth". He then defends naturalists, and himself, of "having introduced ["fait intervenir"] religious considerations in discussions of science"; he explains that geologists who have seen a correspondence between geological facts and the order of creations written in Genesis have not at all called for the authority of sacred books to back up their systems or their explanations. "They have simply noticed a fact which remains outside of any scientific theory; which is this relationship which exists between the results of 
observations today acquired to science and the story of Genesis" (Boubée, in idem; p. 497-498).

This 1846 paper shows that d'Omalius followed the progress of paleontology and other disciplines, evidently exchanged arguments with d'Orbigny and other catastrophists, whose arguments at some point impressed him, and also matured his philosophical attitude. At a time at which many scientists considered the evidence in favour of transformism lacking, he frankly choose it because it was scientifically possible (his criticism of species fixity and geological changes) and because this did fit better his philosophical requirements to do science. The preceding discussion with Agassiz and Boubée shows that scientists had differing appreciations about some, or no, religious influence in the concept of creation. He suspected one, and refused it, which is remarkable if we add that he was himself a religious believer. We know that he was a practicing catholic through the testimony of de Quatrefages (1888), who knew him. We have seen mentions of religious issues in his papers, often detailed in footnotes. He was modern and in line with many other positive scientists in explicitly wanting to separate science from religious questions. However, at the same time, he also liked to discuss theology with his colleagues. According to de Quatrefages (idem), he found in his faith reasons in favor of transformism, which for him was implying a more satisfying view of God. When he later read the Origin of Species, d'Omalius was not surprised by evolution, of course (he is mentioned as a forerunner by Darwin in the second edition), however he did not believe that natural selection would be sufficient to explain the changes which happened in evolution.

In the same years as d'Omalius d'Halloy, Frédéric Gérard, a naturalist and former student of Geoffroy SaintHilaire, also used paleontological knowledge a lot to defend his ideas, which were also clearly transformist. He wrote several notices in the Dictionnaire Universel d'Histoire Naturelle edited by Charles d'Orbigny, the brother of Alcide, published in 1844-1845. In these notices, about species, zoological geography, "degenerescence", he defended transformist ideas, explicitely taken from Lamarck, however expressed in a much more modern way, using a lot of naturalistic knowledge accumulated since Lamarck. In fact, he is the first to have used the expression "theory of evolution of organic forms" ["la théorie de l'évolution des formes organiques"] many years before it became widely used, replacing transformism. He never obtained an academic position, however he was close to the Museum people, and enough scientifically esteemed to have been chosen by Charles d'Orbigny. His later contributions are in botany, a new flora, the edition of a journal for horticulture, etc. More information about Gérard can be found in Laurent (1987) and Molina (1996). Here he is mentioned because he found in the palaeontological knowledge of his time strong arguments in favor of transformism. He also expressed ideas in favor of science and against religious ideas which prevented progress in knowledge. In his paper "De la finalité. Inconciliabilité de cette doctrine avec la philosophie naturelle" (Gérard, 1847), he exposes a history of ideas opposing natural philosophy (or "naturisme", going from facts to interpretations, inductive, since Aristotle, Bacon, etc.), as opposed to idealism (systems based on ideas, metaphysics, Plato, etc., and religious beliefs). He shows the usual link between finalism and religious conceptions, which should not interfer with science. He strongly defends science, and its associated natural philosophy, against contemporaneous arguments in favor of a religious view of science. He cites philosophers (the "true" ones) who follow "Bacon, Newton, encyclopaedists, Buffon, Lamarck, Geoffroy and the greatests thinkers of which science can pride; they study facts, analyse, compare them, and after having drawn the general conclusions to which they can lead, erect theories in which speculative and mystical ideas of their adversaries have no part. The philosophical deduction of naturists is based on the study of analogies and dissimilarities, which reveal them everywhere a uniformity of primitive plan, with parallel series which repeat from group to group, and a real descent ["ascendance"] in organic evolution, in going from simple to compound, and presenting in each ascending group a higher specialisation of functional apparatuses, and in each superior group supernumerary organs, having obscure functions or without important use, because [...] they are only remains of important organs in an inferior group [...] or special organs of the embryonic or foetal life, without use after the growing ["passage"] of the being at a more elevated state." He continues about the study of homologies, of the deep examination of tissues, which "proves the identity of structure in all the series of organized beings"; all these support the doctrine which gives all natural phenomena "a narrow unity"... and steps leading to superior forms are "chronological proofs of the reality of the philosophical theories", based on facts and without metaphysical preoccupations. Then, "studying in the inorganic reign the history of animal evolutions from the deepest to the most recent beds, one sees the same plan unroll also ["également"] in the two reigns, and in correlative relations with the dynamic state of the globe. The verification of the doctrine of the successibility of the beings from the simple to the complex, and not of a sudden and instantaneous creation, becomes more complete." Along his paper, Gérard quotes Linné, who included in his remarkable works religious ideas. He quotes Needham, L. de Jussieu, Adanson, Bonnet, who not only saw in science a simple object of contemplation, but also "anathematized those who gave to science a totally different scope [une "tout autre portée"], and, expecting nothing from revelation, searched in study and reflexion the word of the great work of nature". Continuing his 
history of ideas, he mentions the theories of Burnet, Bay, Leibnitz, and others, on the origin of the earth, which had finalist intent. He also remarks that several religious people elaborated theories which they believed to be not contrary to dogma whereas at his time they are considered heretic (spontaneous generation by Kircher, or species mobility by Linné). Later in his paper, Gérard strongly criticizes Cuvier, who used his power to muffle "Lamarck, who surpassed him of all the difference by which man surpasses child; later he cut down ["comprima"] the doctrine of Geoffroy Saint-Hilaire, who had conquested one of the broadest place in natural philosophy". The memory of his adversaries is avenged by the fact that "Cuvier is just dead, that one already does not talk anymore of his works, his methods are abandoned, whereas the school of natural philosophy is more and more quickly progressing". He then quotes Blainville, famous religious creationist, who had the merit of a complete honesty, declaring that christianity and revelation were the cornerstone of science. Another author, zoologist, Maupied, is also "a christian naturalist who clearly confesses his beliefs", who also treats well his adversaries, including "Lamarck, the best known antagonist of doctrines of finality"; however why does he expresses these beliefs in a public manifestation, which is directed at humans who "come to learn facts, but not to listen to a sermon"? Gérard concludes that there are really two doctrinal schools, one of them being the catholic one, confessed by some scholars but "hidden behind the ambiguous term of finalism, by most of those who retreat in front of the formal expression of their criterium". In his paper, Gérard (1847) comes again at length in criticizing the inconsistencies of those who explain natural facts by their supposed purpose, taking examples from botany and zoology. He criticizes a recent dictionary in which it is written that the visual organs of articulates of the first ages were created perfect at their first origin. Close to the end of his paper, he summarizes that the doctrine of finalism, or perfect creation, is narrow, barren, and only prevents progress. In front of the complexity of what exists, "it is the naturalist who has to search among this maze of facts, to seize the thread of this great law of vital evolution, without laying as a basis, a priori, a doctrine...". He ends his paper with a defense of science, observation, experience, preventing against speculations, and asking that, if scholars personally adhere to abstract doctrines, they should avoid to mix them with their studies. This paper published by Gérard in 1847 reveals how vigorous was the debate in France at that time, concerning transformism, or evolution as commonly used by Gérard, and including associated philosophical and religious considerations.

The numerous contributions of Gérard to a dictionary reveal that transformist ideas were debated in France, despite the common claim that Cuvier having won against Lamarck, theses ideas had been abandoned. On the contrary, Laurent (1987) has shown that Lamarck's ideas were permanently discussed during the first half of the XIXth century, and Molina (1996) notes that, among four dictionaries of natural sciences which played an important role in these decades, one clearly favored fixist ideas, that of Frederic Cuvier, however the three others discussed transformist ideas. Second, we know that the notices for that dictionary were separately published, and that Darwin read and annotated the one on "Espèce" in 1845. Despite the critics of Hooker, he requested him to send the other opuscules of Gérard which appeared. Darwin could see in Gérard a number of examples of variations in plants that would be of interest for him, and the meaning of similar characters used to identify varieties and species (Molina, 1996). Gérard also, as many naturalists of his time, referred to domesticated animals and plants as examples of change, however he never reached the idea of natural selection, because he was continuing to give an excessive role to direct influences of the milieux. Anyway, Gérard was an evolutionist long before 1859 , and a materialist who was looking for natural explanations to evolution. He saw in the evolutionary process two laws, which foreshadow those of Bronn (a law of ascending transformation of types, and a law of temporary variation of a type under the influence of environments; see Laurent, 1987).

\section{REQUEST OF A CREATIVE FORCE BY BRONN AND D'ARCHIAC}

A different scientific approach is illustrated a decade or more later by Bronn and d'Archiac, who could not accept transformism in spite of the increasing fossil record (Bronn may have accepted the idea at the end of his life, when he organized the first translation in German of the Origin of Species). It is very interesting to analyse why Bronn remained opposed to transformism in the years 1850-1858. Born in 1800, Professor at the University of Heidelberg, Bronn had published syntheses in palaeontology, his Lethea Geognostica in 1834-1838, his Handbuch einer Geschichte der Natur (1842-1848, read and cited by Darwin). When the famous prize for "Physical Sciences" was launched in 1850 by the Academy of Sciences in Paris, Bronn had just published his Index Paleontologicus (1848-1849), in which more than 27,000 species are listed. The prize was for an essay "To study the laws of the distribution of fossil organic bodies in different sedimentary beds following their superposition order. To discuss the question of their successive or simultaneous appearance and disappearance. To search for the relationships existing between the present state and the anterior states of the organic reign". The subject was accompanied by a series of more developped questions, concerning the role of catastrophic extinctions, the possible identity of living and fossil species, of species pertaining to successive stages, and: "when a species seems to have disappeared and to have been replaced by a slightly 
different species, one can wonder if the latter results from a new creation or from a transformation of the species which is no more found". This prize accompanied by a costly gold medal, exemplifies that transformism was at the heart of many debates, even at the Paris Academy where successors of Cuvier were predominant (on the committee after 1853, only Isidore Geoffroy Saint-Hilaire, son of Etienne, was a transformist). After the publication of the prize, Bronn immediately started to work. No satisfying essay having been submitted in 1853, the prize was prolonged. Bronn submitted his essay in 1855, was examined in 1856 and crowned in 1857. His work appeared in two papers in German in 1858, and a French version was published by the Academy in Paris in 1861. This work gives an excellent view of the stage of paleontological debates in the decade 1850-1860 (this episode is related in Rudwick, 1976).

Bronn defends the continuity of life, against catastrophists; that there are living species known as fossils, and that there are species known in several successive stages (against d'Orbigny); he has a very gradual vision of the history of faunas. Bronn considers that there are two main laws governing vital phenomena: a law of necessity coming from external conditions (adaptation, order of appearance of species), and a second law of progressive development of successive populations, which occurs "according to a law independent of external conditions and inherent in the creative force itself". However he refuses the intervention of a creator, which he finds inconsequent (why use a creator in the organic world when everything else is under general forces immanent to matter; he refers to Newtonian physics). His creative force is an unknown natural force, the effects of which he describes. Why did Bronn not become a transformist? Laurent (1997) lists three reasons: spontaneous generation is not scientifically accepted (Bronn cites Ehrenberg's experiences); no experience testifies in favor of the transition of one species (or genus or...) to another one; he did not find in the fossil record (27,000 species) a series which would show one species becoming another one. This position is very interesting. It has nothing religious. Bronn even mentions that for a believer a creator presiding the development of organic nature through a force placed in itself, as for the inorganic world, would fit with a much more sublime idea than "if we admitted that he takes continuously care, for the introduction and the change of plants and animals in the aquatic and atmospheric milieux, as does a gardener caring for the cultivation of his garden." Clearly Bronn is excessively trapped in an epistemology of facts and experiences to be able to accept transformism in 18501860 (Laurent, 1997).

The same is true of Adolphe d'Archiac (1802-1868), who had just obtained the chair of paleontology at the Muséum in Paris in 1861, when he reacted very negatively to the publication of Darwin. D'Archiac had been a productive geologist and paleontologist. Between 1835 and 1847 he published studies on the geology of the Aisne Department, on Cretaceous beds of South and Central France, and with E. de Verneuil a memoir on Paleozoic fossils of the Rhenish Provinces (Rhein valley), which played a role in the consolidation of stratigraphy as a valid discipline (Laurent, 1987). He saw that there were species that can be found in several successive stages, against d'Orbigny, and he became progressively more and more sceptical about the extent of the catastrophs as they had been tought to him in 1830. Starting in 1847, he writes syntheses about the recent progresses of geology. The yearly synthesis of geological advances made in the Bulletin of the Société Géologique de France had been stopped, hence he asked and obtained funds to fill the gap in starting a synthesis of these progresses between 1834 and 1845. In fact, the task was enormous, the work took him several years, rendering necessary new updatings; it ended as 8 volumes of synthesis of geological advances between 1834 and 1859 , published in 1847-1860. D'Archiac had not the time to answer the Academy prize, being in the middle of his synthesis work, however, when Darwin published On the Origin of Species, he was very well placed to give the point of view of a paleontologist. He was in fact in the middle of writing a course of stratigraphical palaeontology: the first volume, published in 1862, has no mention of Darwin, the second, published in 1864, has many, including a 50 pages examination of the book of Darwin, second part of his second chapter devoted to Species.

This examination, of the 1862 translation in French (faulty, however he also mentions the original), is devastating. Chapter after chapter, he quotes Darwin and gives subsequent comments, critics or refutations. Doing this, he is sometimes injust or contradictory, however he also points to many weaknesses of the first edition of the Origin, and to its speculative character. Darwin having mentioned about dogs that he was convinced that the blood of several wild species of dogs flowed in the veins of our many domestic races, d'Archiac says that "if these species of wild dogs were able to breed and give fertile products, they were not really distinct species. Or, if the author knows better characters [as continous fertility, to define species], he should have started by indicating them,... To discourse about species, to pretend finding its origin and to not define it, not characterize it, say how it is recognized, exposes oneself to be poorly understood and poorly judged" (d'Archiac, 1864; p. 68). Darwin remarking that naturalists did not pay enough attention to domestic animals, d'Archiac immediately writes how wrong this is: "We will first remark that this study is far from having been neglected, as the author believes. Naturalists who addressed this question, from Buffon to the two Geoffroy Saint-Hilaire, have always relied on examples taken from the results of domestication, and it is precisely what Cuvier reproached to them fourty years ago and on what we will again insist after this great master." "To pretend explaining 
facts, or, if one wants, mysteries that nature conceals to us, by analogies deduced from results that man obtained by chance, by his industry or by his whim, for his utility or his pleasure; trying to interpret the laws of nature, outside of nature itself, by actions which make it so clearly deviate from its true ways; supposing that it procedes, as told Bronn with his witty common sense, as a gardener who chooses his varieties, reproduces and modifies them again, etc., isn't it to make of it [nature] a strange idea, not very worth, we think, of the immensity of the work and the power of the Creator, as, whatever one says, we must always go back to the principle which organizes and which creates" (idem; p. 67). More importantly, Darwin (p. 121) writes that for large modifications to be produced during centuries, it is necessary that a variety, after being formed, varies again, possibly after a long interval of years, and that those variations which are advantageous be again preserved, and so on. D'Archiac comments: "One can conceive, to a certain point, that selection occurs one time, two times, may be three; however if it is a law, it is not the effect of a fortuitous circumstance; it cannot stop to manifest itself during all the cycle that the form is destined to follow; from which it again results, as a necessary consequence ["forcée"], an indefinite perfectioning. [...] However it is in vain that we look around us, that we look into the past, we cannot see what one would call as well a law of progress, expression already used, as a law of selection ["élection"], as one is the consequence of the other" (idem; p. 73). Several pages later, he quotes Darwin writing (p. 175) that natural selection implies no necessary and universal law of development and progress; it only seizes any advantageous variation when it occurs... D'Archiac finds that this is in contradiction with what has been said of organic progress as of the absence of limits to the sum of changes that can be effected during the course of successive ages by the selective power of nature. "It is not actually a general fact, it is not a law, it is only a fortuitous circumstance. The proposition, far from raising to the height of a biological theory, is reduced to an exception in the normal order" (idem; p. 78). All along his review the Vicount d'Archiac is offuscated, outraged by Darwin's book, and it is very interesting to try to understand why. However, it is not easy to disentangle scientific, philosophical, and possible religious arguments in d'Archiac's reaction to Darwin.

First, on the scientific side, his main arguments against transformism are the same as those of Bronn a few years earlier: the latest experiences, very carefully done, refuted spontaneous generation; the occurrence of mollusks and crustaceans in the oldest known beds destroys "the hypothesis that the most perfect beings are coming from secular modifications of anterior less elevated species" (idem; p. 4). A good connaisseur of the palaeontology of his time, to Darwin explaining that any species which does not changes to its advantage as much as its competitors must be almost immediately exterminated, he objects: "The examination of any species, observed not today, because we do not dipose of enough centuries of researches for that, but in the geological times, shows, on the contrary, either the development, in some way spontaneous, of a type which ceases as abruptly, or the gradual development and an attenuation also gradual preceding the extinction of this type; however, if the principle were true, isn't it in the best known geological basins that we should find its confirmation?" (idem; p. 75). The palaeontologist recalls the often quoted fact that many species appear abruptly, stay without change, and disappear abruptly, refuting Darwin's grudualist model. Like most palaeontologists of his time, he thought that there was no evidence of transition between "types". In such conditions, how can one adopt "generalized transformism" (Laurent, 1987)? Not as a consequence of factual evidence. In fact, d'Archiac's scientific view about the history of life is simple. In his "last considerations on the origin of species", he again quotes Bronn: "We do not know any natural force, which produces new species or stumps [sensu stems] of new species" (d'Archiac, 1864; p. 123); despite the role of local physical changes, another general law of nature, unknown, is necessary to explain the observed general changes, the second law of Bronn.

On a more philosophical point of view, Darwin's book did not meet d'Archiac's criterium for science. He concluded its analysis with: "The principle on which it lies from one end to the other is an abstraction which is not the consequence of a series of positive observations; it is not supported by any set of facts demonstrated by the comparative study of the present, nor of the past; it is a simple hypothesis surrounded by innumerable reasonings, quotations and of suppositions no less multiplied, but which do not suffice to dissimulate its weakness" (idem; p. 114). However, d'Archiac was even more opposed to darwinism than to transformism, and this for philosophical reasons. He thought that the struggle for life was unacceptable. Convinced as many of his contemporaries of the harmony of nature, often mentioned in his discussion, he was chocked by the domination in nature of the struggle for life, associated for him with a philosophical fatalism. Fatalism refers to doctrines of those who deny human freedom, "and think that our actions obey to the law of necessity" (Anonymous, 1857). It is probable that d'Archiac understood that Darwin's hypothesis would have far-reaching consequences concerning man. Was he under religious influence? Despite the above mention of the Creator, the reasons behind his general views are probably not religious at first. In his text, he mentions nature's powers many more times than the Creator, and there is no reference to Scripture. He has expressed in the first volume of his course that he is not interested to confront geology and palaeontology with biblical accounts: "However, naturalists who entered this way 
were, for us, completely mistaken, and without realizing, inverted the roles. Theologians only have to seize facts acquired to science, to compare... Philological knowledges and those of the exegetist also are indispensable to treat these questions placed outside of our domain and that we recalled only to declare that we will no more have to bother about them and to prevent any false interpretation in this regard" (d'Archiac, 1862; p. VIII-IX). Isn't it clear? He several times mentions that a gradual and complete plan was followed by nature until now, however he also declares himself opposed to finalism, and writes that "the appearance of man had not necessarily as goal his existence or his pleasure". "But nothing until now proves that man is the goal or last word of creation, that he is, as was said, its crowning" (d'Archiac, 1864; p. 6). He explains that more perfect beings will probably succeed to him, a view which reveals that he was quite free from the usual religious constraints. He noted that Bronn was a spiritualist scholar, and I suspect that he also was a philosophical spiritualist, and probably not a religious person. The conceptions of this great erudite need to be further scrutinized.

\section{GAUDRY}

Albert Gaudry (1827-1908) belongs to the next generation, that which will become evolutionist. His life and works have attracted attention since Rudwick (1976), however some of his conceptions are difficult to analyse. Gaudry started his work by geological studies in 1850 , and after discoveries made in the Greek locality of Pikermi, he spented most of his time doing palaeontology. Some authors believe that he was already a transformist when he wrote a notice on d'Orbigny in 1859, in which he expresses his conviction that this theory was not necessarily a materialist one. Clearly he felt concerned, and declared himself a transformist in 1862 (1865 according to Grimoult, 2000). When the study of the Miocene Pikermi fauna was advanced, he published in 1866 some of the very first figures showing the phylogenetical relationships of species and genera of mammals through time. These studies pleased Darwin, who quoted them in the later editions of the Origin of Species. In a book from 1888, Gaudry relates his enthusiasm when he read the Origin of Species; he subsequently went on the field with the program of finding the ancestors of living animals. He expresses his admiration for Darwin, who opened new avenues of research and as such proved genious (Gaudry, 1888). However he also writes that he does not share Darwin's philosophy. He is very cautious about the mechanisms of evolution, which he rightly says are not accessible to palaeontologists. He remains with the philosophical views of a religious believer when he looked at the history of life on the earth. After having devoted a lot of time to synthesize palaeontological knowledge of his time in his "Enchaînements du monde animal" (three volumes, 1878-1890), he wrote at almost 70 years an essay of philosophical palaeontology, which is in many ways surprising (Gaudry, 1896). He starts doing a broad synthesis of evolutionary history, well informed, summarizing the history of size and diversity, the history of activities (locomotion, prehension) and the history of the senses (vision, hearing, touch). All this lead him to a global view of progress through evolution, including the progress of intelligence, which can be studied through fossil endocranial fillings. The increasing encephalisation of mammals through the Tertiary is already known (starting with Lartet, who did not become an evolutionist). Gaudry comments on a lot of aspects, including animal adaptations, faunas and floras, relative rates of evolution in "inferior" and "superior" animals; he recognizes that the Cambrian is problematic and that there must have been a very long time span before this stage to allow for the development of the first living beings. Along his descriptions and comments, Gaudry is often poetic, lyric and sentimental. We are lucky to live in a world of mammals and birds because, after visits at the Muséum Ménagerie, where it is hard to see reptiles move, he writes that living among dinosaurs would have been very boaring! His main concern through the book is to convince his reader of the reality of evolution, something which was still not accepted by all of his colleagues (de Quatrefages defended species fixity in 1894).

Gaudry does not feel really concerned by the mechanisms of evolution. The doctrine of evolution, which must be based on palaeontology, "does not consist in theoretical views, but in the patient comparison of beings which succeeded eachother during geological times" (Gaudry, 1888 ; p. 17). Palaeontologists have to bring the proofs of evolution, they do not have to "explain the processes ["procédés"] through which the Author of the world produced modifications. This study of mechanisms is, as we saw, what is named darwinism, from the name of the famous scholar who was its principal promoter. [...]; it is physiologists, who make experiences on living creatures, to learn to us how changes appear ["se produisent"] today and must have appeared in the past." (idem; p. 73). In his longer philosophical essay, he writes slightly more: "If there were no breeding between different species, how did transformations occur? Lamarck and more recently Cope talked about the influence of exercise on organs; Darwin studied the role played by natural selection and vital competition; the numerous physical changes produced on earth's surface have had an effect; microorganisms had some importance, etc. However we must confess that until now we understand very little the causes of the transformations of beings" (Gaudry, 1896; p. 201-202). Gaudry then moves to forces and to vital forces. There was change through evolution: a change has to be produced by a force. Many palaeontologists of that time had been led to the misleading question of an evolutionary force. Gaudry, 
who is a religious believer, considers that the creative force of God must have played a role along the history of life. He is lead to this conclusion by his reflections on the vital force. He has been impressed when he visited his colleague Gerbe and watched with him the beating of the heart in a chicken egg which had no movement one day before. "Where is this movement coming from? It is not from the mother, as the egg is separated from her by a hard shell, and as the simple heat of a hatching owen produces the same effect... Again where is this vital force coming from?" (idem; p. 206-207). The following comments are very suprising for us, as Gaudry explains that animated beings cannot produce themselves their vital forces, "because no one can give what he does not have. When we would imagine all the physical and chemical forces, they will never make a vital force, and above all a thinking force. It is the first cause, which is God, who creates forces" (idem; p. 208-209). Such reasoning is for us hard to follow, however we have to remember that physiology had started great advances during his time (especially Bernard in France), however embryology and the functioning of the brain were still very mysterious, and often explained with vitalistic concepts. Also, the usual reference to analyse matter in the middle of the XIXth century was physics, mechanics, in which an object has movement only if a force is exerted on it from outside: matter has no force in itself, it must receive force from outside, the same being true for the living matter, hence the intervention of vitalistic "principles". So Gaudry was led to see God as the direct creative force through his philosophical analyses. He was well aware that, on such questions, opinions differ and his ideas would not be accepted by everybody. Anyway he expresses all along his essay an enthusiastic, admirative view of the history of life on the earth, a history which reveals a plan, and this gives him no problem with his deep, religious beliefs, on the contrary. Gaudry is not only a scientist, he also is a poet, an aesthete, and after all his essay is not a scientific essay, it is a philosophical one. Despite they would be difficult to disentangle, there is more philosophy than religion in this essay (there are mentions of Descartes, Leibniz, Plato and other philosophers, there is none from Scripture, the most abundant are science).

In sum, Gaudry was at the same time a real scientist; positive palaeontology was for him accumulating observations, facts, comparing them, etc. He was an enthusiastic evolutionist, who considered already that phylogenetical hypotheses were "philosophical paleontology". Conscious that he did not share Darwin's philosophical ideas, he had a deeply religious attitude toward nature and toward evolution, as a poet and aesthete. Inasmuch as he saw the action of God in evolution, he would be one of the few to deserve the term theistic evolutionist. Probably Agassiz would also deserve this qualification (Hull, 1973). In Gaudry's views, it is not simple to distinguish philosophical considerations, e.g., a clear spiritualist commitment and recourse to a God of philosophers, and more explicitly religious choices, in the absence of any recourse to revelation or Scripture.

\section{CONCLUDING REMARKS}

This very short and somewhat arbitrary survey will lead to a few remarks. Concerning the history of science, it is clear that transformism was well known and discussed all along the first half of the XIXth Century in France, Germany and around, even if the followers of Cuvier occupied the dominant positions in the most prestigious Parisian institutions (Laurent, 1987; Corsi, 1988). Clearly, despite he did not mention Lamarck directly in this context, d'Orbigny took care of addressing the Lamarckian factors and their possible role through time. It is the Academy which launched the 1850 prize, and the latter shows that palaeontology was expected to give evidence for or against transformism.

Transformism, or evolution (or change through reproduction, or theory of development, or succession, or etc.) was accepted by a few geologists, and rejected by many geologists and palaeontologists. For what kind of reasons? As was evident in our examples, these rejections were emphatically for scientific reasons. Not to mention the biological problem of species fixity, the fossil record until 1860 simply did not favor evolution. The great majority of the fossils described then were marine invertebrates, in which it is hard to find good examples of macroevolution. The fact that many marine species appear abrutly in marine beds, show some duration without change, and disappear also abruptly has served in the last decades to elaborate the model of punctuated equilibria. Instead of looking at nineteenth century palaeontologists with contempt, we should recognize the accurateness of their observations and their rational coherence.

It is no chance that d'Omalius d'Halloy in his book first pointed to the intermediate stage of the few known Eocene mammals to infer transformism. It is the mammal fossil record which would later give evidence of macroevolution to Gaudry and Rütimeyer, and later almost proof of evolution when the rich fossil record from the North American West would be uncovered. At his time, d'Omalius d'Halloy did confess that this view was not "true science" and was also issued from philosophical considerations about natural science. Indeed, it is not only through the mammal fossil record but through the entire fossil record that big issues had to be discussed, and marine invertebrate fossils were far more numerous than mammals. This allowed d'Orbigny to refute transformism and elaborate his catastrophist views. The appreciations of the completeness of the fossil record differed: d'Omalius 
(1846) insisted that palaeontology was in its infancy. Others, who had accumulated information about more than 20,000 fossil species, felt they could say something. To Darwin, who was asking for intermediate fossil forms, d'Archiac answered: "if each formation, or even each bed, is not full of these transitory forms, it is because these have not existed". In sum, the palaeontologists who doubted transformism before 1870 had scientific reasons for that in their own discipline. Moreover, the scholars we have seen had a very strong commitment to science.

In consequence, the views of these scientists should also be treated carefully when historians come to the difficult concept of creation. As appeared clearly above, d'Orbigny, Bronn, and many others, had a view of creation by natural processes, natural laws. They should not be suspected of hidden religious influences. There were differences in their versions of natural creationism, from the catastrophist view of d'Orbigny, to the much more continuous view of Bronn and d'Archiac. There was also a religious nuance in some, as shown in the text of Brongniart. Another confirmation that their views were not religious is that the two laws of Bronn were widely accepted, including by the materialist Gérard. The search for natural laws of creation was a common theme in nineteenth century science and was not religious in essence. This does not mean that ideological preconceptions did not play a role, Gérard being a materialist and de Blainville, who was opposed to transformism, being clearly constrained by his religious beliefs. Many others were, more or less, and social influences did play a role. However, to make the story one of general confrontation between science and religion is wrong. The story is much more complex. Many scientists wanted explicitly to separate science from religion, including the very catholic d'Omalius d'Halloy. Gaudry, who was an evolutionist and religious, is surprising by his theistic view of evolution; however, he also was conscious that this was a philosophical choice, which would not be accepted by all. As Gérard (1847) forcefully requested, it was mandatory to separate science from religion. However, this was probably easier to say than to do, because philosophical appreciations of their respective limits differed.

This brief survey illustrates the variety of attitudes among a set of scientists who made great advances in palaeontology at that time. The spectrum goes from a materialist, Gérard, to deep religious, D'Omalius d'Halloy and Gaudry. Beyond their strong commitment to science, they tried to separate scientific from religious preoccupations. Several of them deserve further study, to better understand their philosophical background (especially d'Archiac). A better understanding of the debates of the XIXth century, and of the respective role of science, philosophy and religion, would probably help solving some persisting misunderstandings in our XXIst century (religious creationism, see Numbers, 2006). In
2009, a well known weekly magazine in France made a cover with Darwin and a fragment of Michelangelo in the Sixtine chapel showing the creative digit of God, with the title: "200 years after Darwin the war continues"; and below in very large capitals: "GOD AGAINST SCIENCE". It might be time to avoid such misleading icons of publicity, as they can only maintain confusion in the public. The two domains are separated, as shown by the varied religious attitudes found among palaeontologists and all scientists in the XIXth as in the XXth century. A honest history of palaeontology should play its role in this matter: help discover the remarkable lives and efforts of early palaeontologists, as well as help the enthusiastic discovery of the history of life on the earth.

\section{ACKNOWLEDGMENTS}

I thank P. Corsi, M.-C. Groessens-van Dyck, R. Numbers and my wife Y. Larabi-Godinot for the communication of documents which helped me a lot. An anonymous reviewer and A. Delgado made useful suggestions on an early version of this paper.

\section{REFERENCES}

Anonymous. 1857. Fatalisme. In: Dictionnaire Français Illustré et Encyclopédie Universelle, Tome I (dir. Dupiney de Vorepierre, B.). M. Lévy Frères, Paris.

Archiac, A. d'. 1862. Cours de Paléontologie stratigraphique. Première année. F. Savy, Paris.

Archiac, A. d'. 1864. Cours de Paléontologie stratigraphique. Première année - Deuxième partie. F. Savy, Paris.

Bont, R. de. 2007. A serpent without teeth. The conservative transformism of Jean-Baptiste d'Omalius d'Halloy (17831875). Centaurus, 49, 114-137.

Bourdier, F. 1960. Quelques aperçus sur la paléontologie évolutive en France avant Darwin. Bulletin de la Société géologique de France, (7) 57, 881-896.

Brongniart, A. 1857. Rapport sur le Grand Prix des Sciences physiques pour l'année 1856 (relatif aux changements des Etres vivants à la surface de la terre pendant les diverses époques géologiques). Comptes-Rendus de l'Académie des Sciences, 44, 209-228.

Cohen, I.B. 1985. Revolution in Science. Harvard University Press, Cambridge.

Corsi, P. 1988. The Age of Lamarck. University of California Press, Berkeley.

Gaudry, A. 1888. Les ancêtres de nos animaux dans les temps géologiques. Baillère et Fils, Paris.

Gaudry, A. 1896. Essai de paléontologie philosophique. Masson, Paris.

Gérard, F. 1847. De la finalité. Inconciliabilité de cette doctrine avec la philosophie naturelle. Revue scientifique et industrielle, 29, 355-375. 
Grimoult, C. 2000. Le développement de la paléontologie contemporaine. Droz, Genève.

Groessens, E. \& Groessens-van Dyck, M.-C. 2007. D’Omalius d'Halloy - Un scientifique très éclairé. $A F C H A B$, Ottignies-Louvain-la-Neuve, 722-729.

Hull, D.L. 1973. Darwin and his critics. The reception of Darwin's theory by the scientific community. The University of Chicago Press, Chicago.

Laurent, G. 1987. Paléontologie et évolution en France 18001860. Editions du C.T.H.S., Paris.

Laurent, G. 1997. Paléontologie et évolution: Etat de la question en 1850 d'après l'oeuvre de Heinrich-Georg Bronn (1800-1862). In: De la géologie à son histoire. Editions du CTHS (Comité des Travaux Historiques et Scientifiques), Paris, 175-188.

Laurent, G. 2002. Alcide d'Orbigny entre Cuvier et Lamarck. Comptes-Rendus Palevol, 1, 347-358.

Molina, G. 1996. Gérard (addition). In: Dictionnaire $d u$ Darwinisme et de l'Evolution, Vol. 2 (dir. Tort, P.). Presses Universitaires de France, Paris, 1895-1901.

Numbers, R.L. 2006. The Creationists. From scientific creationism to intelligent design. Harvard University Press, Cambridge.

Omalius d'Halloy, J.-B. d'. 1831. Eléments de Géologie. F. G. Levrault, Paris.
Omalius d'Halloy, J.-B. d'. 1846. Note sur la succession des êtres vivants. Bulletin de la Société géologique de France, (2) 3, 490-497.

Orbigny, A. d'. 1840. Paléontologie Française. Description zoologique et géologique de tous les Animaux Mollusques et Rayonnés fossiles de France. Vol. I. Terrains Crétacés. Cosson, Paris.

Orbigny, A. d'. 1842. Paléontologie Française. Description zoologique et géologique de tous les Animaux Mollusques et Rayonnés fossiles de France. Vol. II. Terrains Crétacés. Cosson, Paris.

Orbigny, A. d'. 1850. Lecture d'un extrait du Prodrome de paléontologie stratigraphique universelle. Bulletin de la Société géologique de France, (2) 7, 99-111.

Orbigny, A. d'. 1852. Cours élémentaire de Paléontologie et de Géologie stratigraphiques, Vol. II, fasc. 2. Masson, Paris.

Quatrefages, A. de. 1888. Le transformisme, la philosophie et le dogme. Revue Scientifique, 20, 609-616.

Rudwick, M.J.S. 1976. The Meaning of Fossils. The University of Chicago Press, Chicago.

Vénec-Peyré, M.-T. 2002. Alcide d'Orbigny (1802-1857): sa vie et son œuvre. Comptes-Rendus Palevol,1, 313-323. 
